\title{
Spelling Mastery via Google Classroom among Year 4 Elementary School ESL Students during the COVID-19 Pandemic
}

\section{Emily Lau Yen Yen ${ }^{1}$ Maslawati Mohamad $^{2 \rtimes}$}

${ }_{1,2}^{1}$ Faculty of Education, Universiti Kebangsaan Malaysia, Malaysia. :Email:elyy@edidik.edu.myTel: +60173815593

Email:maslawati@ukm.edu.my Tel:+60133270680

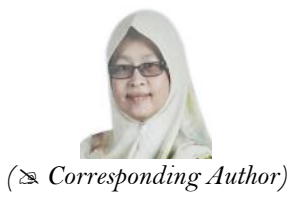

Abstract

Spelling mastery is an important prerequisite of proficiency in the English language. The conventional language teaching strategy needs to be revolutionized for the 21 st century by utilizing Information and Communication Technology (ICT) to enable English as a Second Language (ESL) students to master spelling. As such, online teaching and learning becomes a crucial strategy to impart and receive knowledge. This case study focused on teaching spelling mastery via Google Classroom to elementary school ESL students, coincidently during the unprecedented COVID-19 pandemic which has resulted in the emergence of a new norm in education. This case study involved thirty mixed-proficiency Year 4 ESL students from a suburban national primary school in Selangor. These students were divided into two groups, the experimental and control groups. The experimental group comprised a class of fifteen students who participated in the intervention, whereas the control group consisted of another fifteen students who did not participate in the intervention. The research instruments included pre- and post-test results, field notes and semi-structured interviews. To maintain the integrity of the data, the researchers took the necessary measures to ensure that the instruments were reliable and valid. This included assessing the content and face validity of the research instruments, expert validation for the interview questions and adequate engagement in data collection. The principal findings regarding the use of Google Classroom revealed students' improvement and increased motivation in mastering spelling.

Keywords: Spelling mastery, English Language, Elementary school ESL students, 21st century learning, Google Classroom, COVID-19 pandemic.

Citation | Emily Lau Yen Yen; Maslawati Mohamad (2021) Spelling Mastery via Google Classroom among Year 4. Elementary School ESL Students during the COVID-19 Pandemic. Journal of Education and e-Learning Research, 8(2): 206-215.

History:

Received: 19 February 2021

Revised: 22 March 2021

Accepted: 26 April 2021

Published: 24 May 2021

Licensed: This work is licensed under a Creative Commons Attribution 3.0 License $($ (c) $)$ Er

Publisher: Asian Online Journal Publishing Group
Acknowledgement: Both authors contributed to the conception and design of the study.

Funding: This study received research grant from the Faculty of Education, Funding: This study received research grant from the Faculty of Education,
Universiti Kebangsaan Malaysia (GG-2020-015). Universiti Kebangsaan Malaysia (GG-2020-015).

Competing Interests: The authors declare that they have no conflict of interests.

Transparency: The authors confirm that the manuscript is an honest, accurate, and transparent account of the study was reported; that no vital features of the study have been omitted; and that any discrepancies from the study as planned have been explained.

Ethical: This study follows all ethical practices during writing.

\section{Contents}

1. Introduction .

References.. 


\section{Contribution of this paper to the literature}

This study investigated the effects of using Google Classroom to enhance spelling mastery among Year 4 elementary school English as Second Language (ESL) students during the Movement Control Order (MCO) due to the COVID-19 pandemic.

\section{Introduction}

The English language serves as the global lingua franca and, in Malaysia, is considered the second language (Thirusanku \& Yunus, 2014). The goal of aligning English language education in Malaysia with the Common European Framework of References (CEFR) is to enable elementary school ESL students to become proficient in the language (Ministry of Education Malaysia, 2018).

Spelling is fundamental to learning English as a second language. Despite this, elementary school ESL students have difficulties with spelling, due mostly to their lack of spelling knowledge, confusion about the spelling of words and mother tongue interference. Cook (1997) identified four major types of spelling error. They are addition (including additional letters), substitution (replacing incorrect letters), transposition (changing the position of the letters) and omission (leaving letters out). This study concerns the ESL spelling mastery of Year Four elementary school students in a Malaysian school. The L1 of the Year Four students is Bahasa Melayu (BM) while English is their L2. The interference between BM and the English language is one of the major causes of the students' spelling errors (Bakar, Fauzi, Yasin, \& Yunus, 2018).

Following the highly contagious and rapid spread of the COVID-19 pandemic in Malaysia, the government declared a partial lockdown in order for the country to curb the spread of the disease (Rahman, 2020). Malaysians must comply with the so-called Movement Control Order (MCO). As such, online learning has become a necessity as everyone, including school students, is required to stay at home to break the chain of transmission of the virus., Teaching and learning are therefore conducted online. Administrators have trained the government school teachers to use Google Classroom. After their training, most teachers use Google Classroom to deliver their lessons. Hence, the main purpose of this study is to determine the effectiveness of Google Classroom for mastering spelling among elementary school ESL students during the Movement Control Order (MCO) imposed by the COVID-19 pandemic. The following research questions have been formulated:

1) What is the elementary school ESL students' spelling mastery before and after utilizing Google Classroom during the COVID-19 pandemic?

2) What is the elementary school ESL students' perception of mastering spelling via Google Classroom during the COVID-19 pandemic?

\section{Literature Review}

\subsection{Spelling}

In Malaysia, due to the history of British colonization, words are spelled according to British English spelling conventions (Amin, 2012). Words are spelled differently depending on the conventions of the specific variety of English, for instance, "yogurt" (American English) or "yoghurt" (British English). Therefore, students need to be aware of the differences.

Moreover, Perveen and Akram (2014) stated that, although proficient ESL spellers may spell most words correctly, there are also some words which they often tend to misspell. Likewise, Westwood (2014) expressed that students' misspelt words influenced the quality of their written work. One of the reasons is that, in English, spelling does not consistently conform to specific speech sounds. Similarly, Bakar et al. (2018) asserted that English spelling could be challenging for students because there are words that sounded similar (homophones) but differ in their spelling and meaning, for instance, "week" (a period of seven days) and "wig" (a hairpiece) display distinct meanings yet have a similar pronunciation. In addition, the inconsistency of the English spelling of loanwords from languages such as Spanish, French and Latin creates spelling confusion, for example, "omelette".

Furthermore, the influence of mother tongue interferences is also a challenge to the mastery of spelling. Samuddin and Krish (2018) discovered that a major concern in L2 (English) spelling among Malay elementary school ESL students is the opaque orthography of the English language which vastly differs from their L1 (BM). The words in BM are usually spelt according to their pronunciation, which influenced the ESL students' spelling of English words. An example that reflected their confusion is the English spelling of the word "mosquito". The students instead spelt the word "moskito".

A good grasp of English spelling is crucial for these students, as clarity in writing depends on accuracy in spelling. Because 21 st-century learning involves communication in the form of writing, it is necessary to write sentences with correct spelling (Treiman, Kessler, \& Caravolas, 2019). Spelling mastery is an essential foundation for learning other English language skills. Hence, teachers need to closely guide these students to build their spelling repertoire and, in doing so, the teachers need to successfully link the new information to the students' cognitive framework.

\subsection{Online Learning}

Hashim (2018) defined the process of language learning which takes place via an online platform as Technology Enhanced Language Learning (TELL). There are many studies on TELL; however, little attention has thus far been devoted to the area of spelling in the ESL context among primary school students (Lau \& Maslawati, 2020).

Krashen (1985) had much earlier hypothesized that anyone should be able to attain a second language if they are presented with comprehensible input and have a sufficiently low affective filter level to allow the input 'in'. Botley, Faizal, and Dillah (2007) demonstrated that the number of spelling errors in tertiary students' writing in CALES (Sabah/Sarawak Corpus Database of Students English) showed a decrease as a result of their confidence with online spelling exercises. Online learning allows students to feel confident even when they make spelling mistakes due to the absence of their teacher and classmates. Thus, it creates a low affective filter atmosphere for 
learning spelling. In contrast to the usual rote memorization strategy, online learning offers more flexibility, particularly in mastering spelling, as noted by Sarris and Panagiotakopoulos (2011).

Additionally, Randhawa and Saroa (2014) conducted a research survey concerning spellchecker software. The activities in the software are designed to enable the students to receive regular feedback in tracking their misspellings and provide recommendations for the misspelt words. Hence, teachers who regularly use Education 4.0 tools should promote digital literacy to ensure meaningful practice among the students. This would be in accordance with the Theory of Behaviorism, according to which Lim, Tang, and Kor (2012) suggested that a progression of building blocks for meaningful learning could be created through multiple repetitions, drilling practice and engagement.

Bakar et al. (2018) discovered that their elementary school ESL participants were able to improve their spelling via an online platform known as Telegram Autobot, which permitted them to picture the words in their minds before having to spell them. Subsequent qualitative methodologies revealed the participants' positive responses in mastering the spelling of the words after participating in the intervention.

Besides, Supardi and Hasanah (2020) argued that online learning enables students to accomplish their tasks with the aid of technology in a way that allows knowledge to be simultaneously imparted and acquired. This is particularly the case in the complete absence of physical classroom sessions during MCO due to the COVID-19 pandemic, as in this study. Chung and Yunus (2021) in their research discovered that students were exposed to a productive language environment, since they had the opportunity to communicate and study virtually with others. The concept of the More Knowledgeable Other (MKO) was applied to the participants who were more proficient at sharing their language knowledge with their peers. According to Vygotsky (1978) MKO refers to an individual who is more able to do a particular task than a learner.

Previously, Simin and Sani (2015) also suggested that an active learning environment could be created through the use of ICT in education. Active learning is a type of student-centered learning in which students are engaged in meaningful thought and learning processes, which aligns with constructivist epistemology (Cattaneo, 2017). One of the reasons Google Classroom was used as an online learning platform in this study was also because Lynch (2018) suggested that the interactive features of Google Classroom could stimulate interest in learning, which could promote active learning.

As pointed out by Ahmadi (2018), the genuine relationship between technology and teaching methods is vital in changing the students' perception and encouraging them to master spelling. This is particularly helpful during the COVID-19 pandemic, in which online learning is the only accepted medium in the educational field and has become the new normal.

\subsection{COVID-19 Pandemic and The New Norm of Education in Malaysia}

COVID-19 is an acronym for Corona Virus Disease 2019 (World Health Organization, 2020). According to the World Health Organization (2020), the virus originated in Wuhan, China in the Year 2019 and is highly contagious. Many countries worldwide, including Malaysia, have declared either a partial or full lockdown as part of their continuing efforts to combat its rapid spread. The World Bank (2020) stated that the virus has contributed to the worldwide closure of educational institutions affecting millions of educators and students.

"It has become a catalyst in moving the world towards a digital future besides being the only choice during this confinement period," said Professor Dr. Abdul Karim Alias from Universiti Sains Malaysia, as reported by Rahman (2020). This digital move involves educational stakeholders at all levels - from elementary to tertiary education.

In light of this, even telecommunication companies in Malaysia have pitched in, offering a daily $1 \mathrm{~GB}$ of free mobile data to their users as part of their community services in light of the COVID-19 pandemic (Yeoh, 2020). This provision could enable teachers and students (with their parents' assistance) to take the opportunity to continue their teaching and learning processes through online learning.

Throughout this period, Malaysian teachers have been very proactive, in compliance with the SOP issued by the Education Ministry (Lee, 2020). They have utilized online learning platforms such as Google Classroom and instant messaging apps such as WhatsApp and Telegram, while preserving their own and their students' privacy.

According to Mahalingam and Md Yunus (2017), good language students are capable of adapting quickly to fit in with their environment. Online learning platforms can optimize students' potential and aid them in acquiring a second language. Bakar et al. (2018) concluded in their research that the integration of technology in teaching and learning perpetuates meaningful and productive learning.

Google Classroom is a new online learning platform distinguished by a student-centered approach that can assist elementary school ESL students in learning to spell. Hashim (2018) found that virtual learning is distinctly user-friendly and flexible. It can be utilized according to the teacher's and students' convenience within a scheduled period - provided Internet connectivity can be sustained.

Rahman (2020) opined that it is possible to sustain the educational system, now it is faced with the new normal of education during the COVID-19 pandemic, if online learning is implemented with the utmost urgency. It is hoped that even while in the midst of overcoming the pandemic crisis, these students will excel in their spelling mastery by utilizing Google Classroom.

\section{Methodology}

\subsection{Research Design}

For this research, a qualitative case study approach was deemed suitable as a research design. This is because the researchers' interest was to unravel a process of one or more than one individual at length in its natural setting, as proposed by Creswell (2014) and Fraenkel, Wallen, and Hyun (2015).

Creswell (2014) defined a case study as a period of investigation into a case and the product of this inquiry. The current study was created to investigate the participants' challenges in attaining spelling mastery in the English language during the COVID-19 pandemic. 


\subsection{Population and Sample of the Study}

Purposive sampling was employed in this case study in order to focus on those participants from which the most could be learned, as also supported by Creswell (2014). This group of participants was chosen because they were able to fulfill the criteria determined by the researchers as most promising to provide answers for the two research questions in the study.

Two criteria were employed in selecting the participants. When deciding the demographic sample of the study, the first criterion was to determine the availability and reliability of the Internet connection in the prospective participants' homes to ensure the intervention could be carried out smoothly. The selected participants confirmed that they had Internet access in their homes that allowed them to access the e-learning platform on Google Classroom using either a mobile phone, tablet or computer amid the MCO.

The second criterion was that they represented the English Language mixed-proficiency group. A Year Four ESL class in a suburban primary school in Selangor was purposively chosen for this research based on these two criteria. Reflecting on the mid-term evaluation of the participants' achievements in their English Classroom-Based Assessment (CBA), they ranged from Band 2 to Band 5. This indicated their English Language level qualified as mixed-proficiency. The study adopted the practice of whole-class discussion and individual tasks.

\subsection{Participants}

The participants were thus 30 Year Four (aged ten years old) mixed proficiency ESL students from a suburban national elementary school in Selangor. These students were divided into two groups, namely, the experimental and control groups. The experimental group was comprised of a class of fifteen Year Four ESL students who participated in the intervention. On the other hand, the control group was comprised of another class of fifteen Year Four ESL students who did not participate in the intervention. They were all Malays, meaning that their L1 was the Malay language (Bahasa Melayu) and English was considered their second language.

Most of these students tended to make spelling errors and had difficulty spelling words correctly in the tasks assigned to them in their regular English lessons. As such, an attempt was made to select them through purposive sampling to help solve their spelling problems. They had access to digital devices and Internet connections, thus enabling them to fulfill the criterion of being able to access Google Classroom during MCO, as required for the study.

\subsection{Procedures}

Before the intervention, all the participants were required to answer online pre-test questions that tested their spelling of 50 words. The students had already learnt these words in the first five modules of their Year Four 'Get Smart Plus 4' English textbook. These were 'Module One: Where Are You From?', 'Module Two: My Week', 'Module Three: In the Past', 'Module Four: Celebrations' and 'Module Five: Eating Right'.

Next, one of the researchers conducted the intervention. In each lesson, she uploaded ten pictures with audio pronunciation of the word for each picture. The participants in the experimental group had to identify and discuss the spelling of the words as a whole-class discussion, after which they typed them out in the comment section and were instructed to correct each other's work.

Subsequently, these participants accessed a Google Form via Google Classroom to individually attempt the spelling quizzes. These consisted of ten multiple-choice questions with pictures and audio pronunciation of the words, and the participants were asked to choose the best option from a selection comprised of only one correct answer with three others as distractors. This activity was repeated for five consecutive weeks using one module per week, from Module One to Module Five.

Field notes were taken during the intervention process to collect observations on the students' progress throughout the intervention. After the intervention, an online post-test, with similar questions regarding the spelling of 50 words to the pre-test, was carried out to compare all the participants' performances against the pretest. Finally, a semi-structured interview was also conducted with the participants after the intervention to identify their perceptions of the intervention. The individual interview sessions were conducted for approximately thirty minutes per session, as suggested by Jamshed (2014), for the three different categories of participants (low, intermediate and advanced).

\subsection{Research Instruments}

The method of triangulation was applied through the use of various data sources to corroborate the findings of all the data from the research instruments (Fraenkel et al., 2015). The research instruments used to collect the data were the pre- and post-test, document analysis, field notes and semi-structured interviews. These were used to identify whether the intervention was helpful and served to answer the research questions. The rationale for the document analysis and pre-test was to evaluate the spelling achievements of the participants before the intervention and the post-test served to study the effects of the intervention.

The spelling questions for the pre- and post-tests were based on the word lists used in the current Year Four 'Get Smart Plus 4' English textbook. Since the participants had studied up to and including Module Five in the textbook, ten words were selected from each module from Module One to Module Five; thus totaling 50 words that were tested. The online activities were aimed to improve the participants' spelling ability by the end of the study. They had been familiarized with these words before the intervention through the learning method of rote memorization.

All the participants answered similar sets of questions in both the pre- and post-test. The pre- and post-test used in this study were the subjects of the content validity test, as they were used to identify the effectiveness of using Google Classroom for the mastery of spelling among the participants, made necessary by the MCO during the COVID-19 pandemic. Ary, Jacobs, and Sorensen (2010) postulated that evidence based on test content is crucial in evaluating test performance, since the participants need to perceive the items as relevant according to the focus of the study. A further term used in connection with test content is face validity (Ary et al., 2010). This is used to describe the subjective belief that the instrument measures what it should measure. The document analysis and 
pre- and post-tests were believed to have face validity since the participants were tested on the words they had previously learnt.

The perceptions of the participants with regards to the Google Classroom intervention were also recorded. As argued by Fraenkel et al. (2015), observation does not merely involve vision but other senses as well. Therefore, observation consists of more than just recording the data from the environment. In this study, field notes were used to collect data; an independent observer was called to assist with the observation to eliminate any bias in judging the effectiveness of the lessons.

The researcher constructed the semi-structured questions for the interview, which were then passed to two experts to be reviewed. An expert is defined as a person with adequate domain knowledge, expert psychological features and the ability to apply appropriate decision-making strategies (Fraenkel et al., 2015). Correspondingly, the two experts reviewed the clarity, redundancy, readability and completeness of the interview questions.

The interviews were conducted to determine the participants' perceptions after the intervention to obtain their feedback regarding the intervention and whether it assisted them in their mastery of spelling during the MCO due to the COVID-19 pandemic.

\subsection{Data Collection}

Formal approval from the school's headmaster was obtained to proceed with the data collection. The data collected from the participants' performance in the pre- and post-test as well as the document analysis were compared, evaluated and analyzed to determine the participants' improvement. Their perceptions of the intervention were assessed based on the field notes and the semi-structured interviews. The data thus collected were used to assess whether the objectives of the intervention were achieved.

\section{Findings and Discussion}

4.1. Participants' Spelling Mastery

\section{The English Language spelling should be using British English variety}
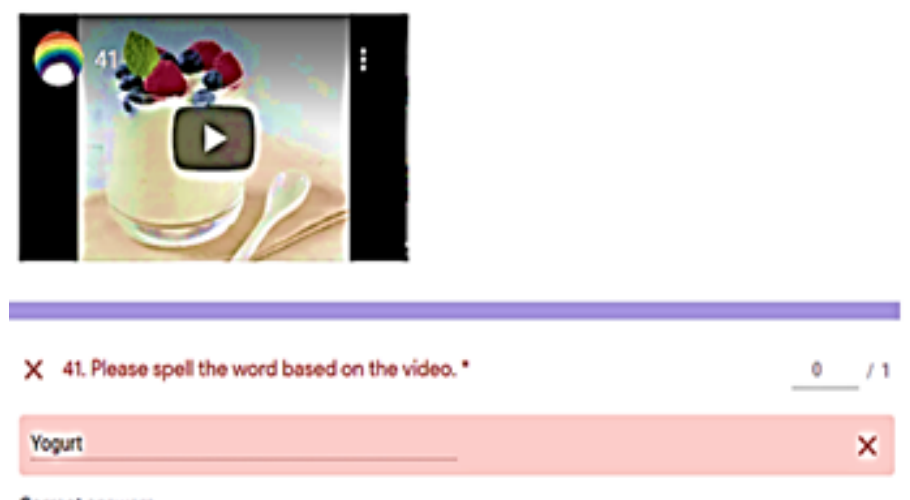

Correct answers
yoghurt
yoghurt

\section{Homophones}

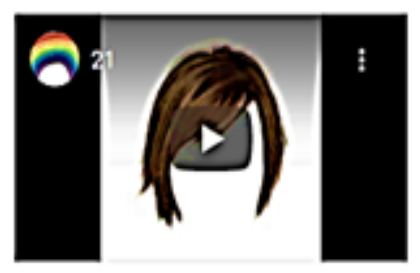

$\times$ 21. Please spell the word bosed on the video."

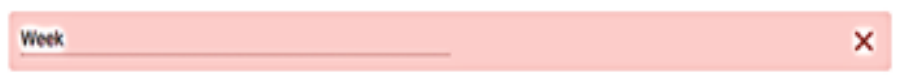

Correct answers

mo

Wh
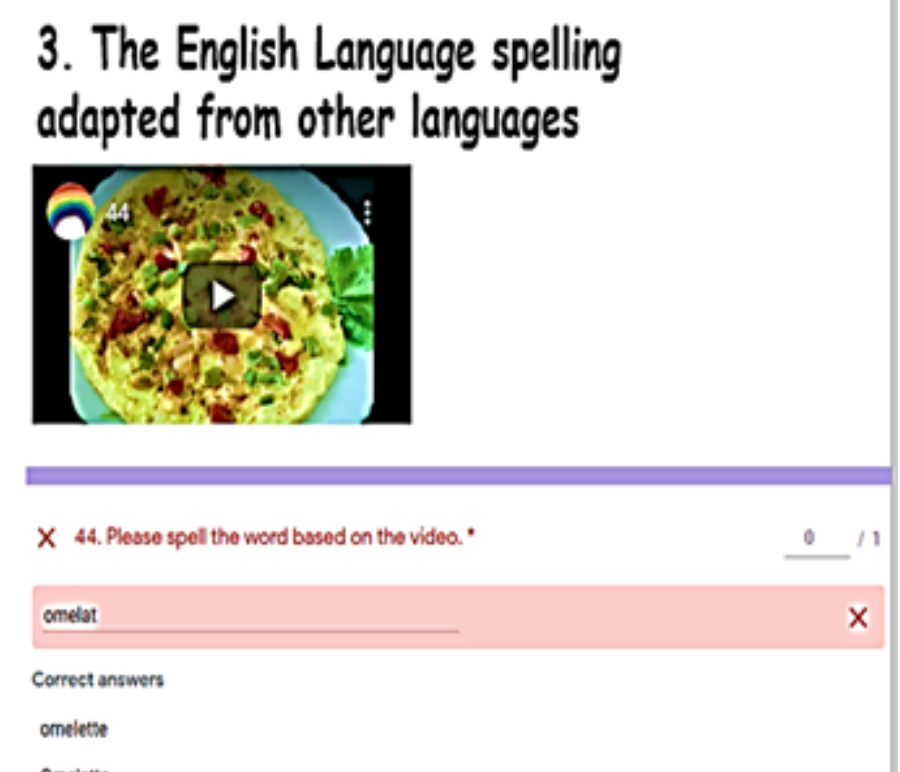

4. L1 to L2 interference
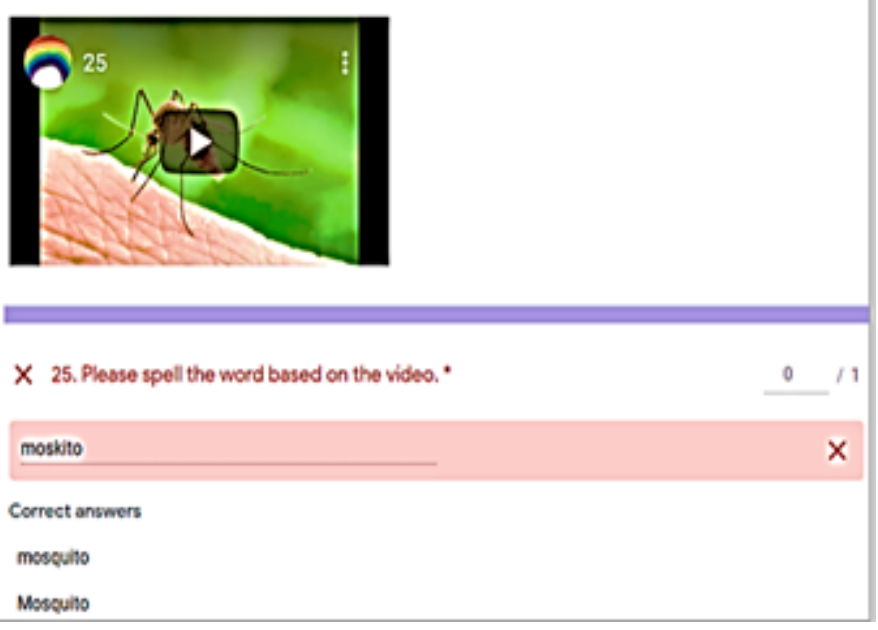

Mosoulo

Figure-1. Example of spelling mistakes and errors made by Participant 1 before the intervention (pre-test). Source: Pre-test of the intervention.

Figure 1 illustrates a selection of the various spelling mistakes and errors made by Participant 1 in his pre-test, before the intervention. Certain errors were made due to the inability of the participant to correctly distinguish between the British English or American English spelling of words, causing him to misspell the word as "yogurt" instead of the correct spelling of "yoghurt". Next, homophones accounted for another category of errors, in which the pronunciation of two different words with a different spelling may be similar, causing the participant to make mistakes in his spelling of the word "wig", instead spelling it as "week". Interestingly, some English language spelling errors were adopted from the participants' L1, which caused Participant 1 to erroneously use the spelling "omelat" instead of "omelette". BM spelling also influenced the participant's spelling of the word "moskito" instead of the correct English spelling, "mosquito". 

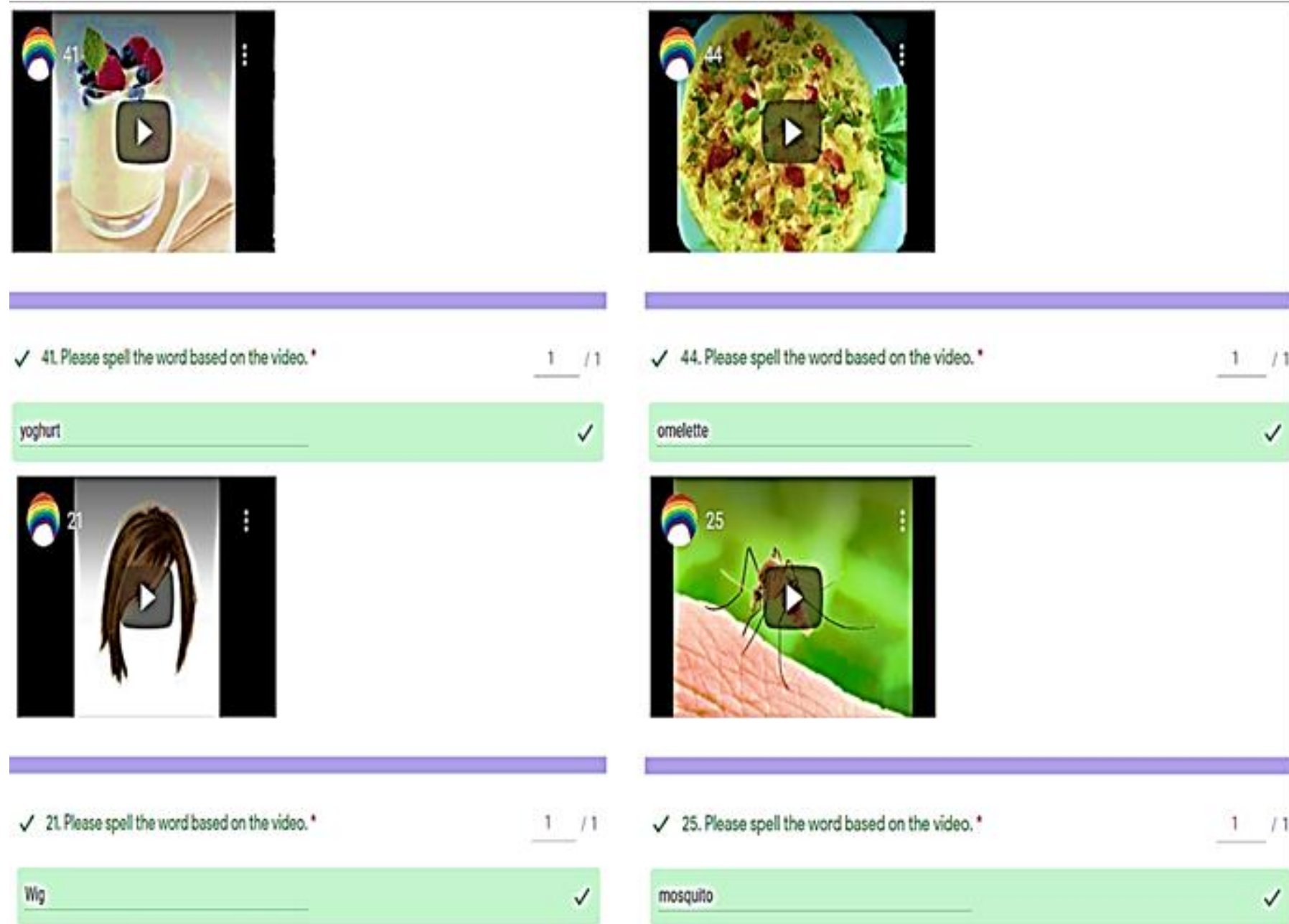

$\checkmark$ 25. Please spell the word based on the video. * Figure-2. Example of the correct spelling of words by Participant 1 after the intervention (post-test).
Source: Post-test of the intervention.

By contrast, in Figure 2, it can be observed that in his post-test after the intervention Participant 1 managed to spell the four words correctly, indicating an improvement in his spelling mastery. Other participants also showed improvement in their spelling of words after the intervention. The results overall proved that the participants obtained better results in the post-test.

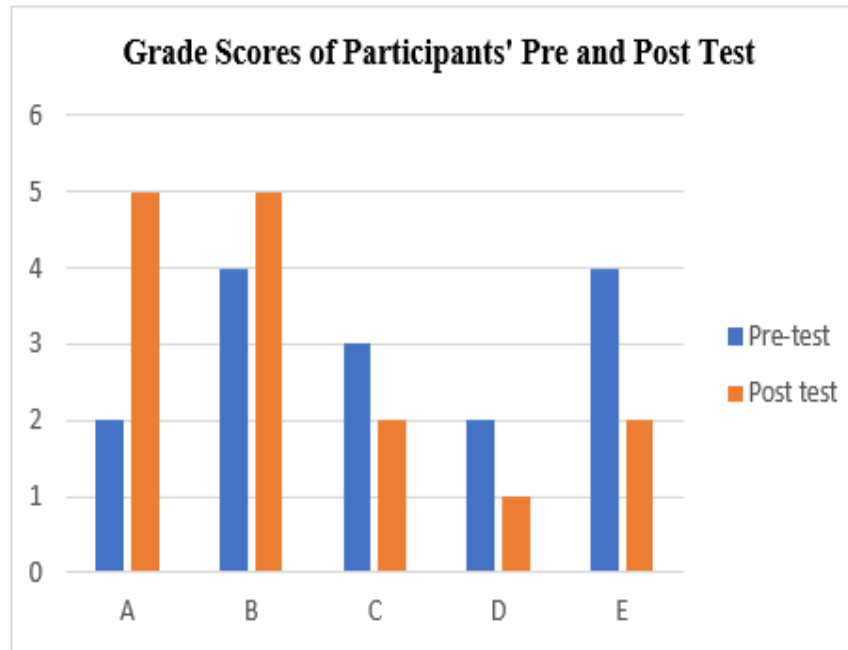

\begin{tabular}{|c|r|r|}
\hline \multirow{2}{*}{ Grades } & \multicolumn{2}{|c|}{$\begin{array}{c}\text { Number of } \\
\text { Participants }\end{array}$} \\
\cline { 2 - 3 } & Pre-test & \multicolumn{1}{|c|}{ Post-test } \\
\hline A & 2 & 5 \\
\hline B & 4 & 5 \\
\hline C & 3 & 2 \\
\hline D & 2 & 1 \\
\hline E & 4 & 2 \\
\hline Total & & 15 \\
\hline
\end{tabular}

Figure-3. Spelling grade scores of participants' pre- and post-test (experimental group).

Source: Pre- and post-test of the intervention.

The bar chart in Figure 3 shows the spelling grade scores of the pre-tests and post-tests of the fifteen participants (experimental group). The number of participants who obtained grades A (increased from 2 to 5 ) and B (increased from 4 to 5) showed a significant difference between the pre-test and post-test results. In contrast, the number of participants who obtain grades $\mathrm{C}$ (decreased from 3 to 2 ), $\mathrm{D}$ (decreased from 2 to 1 ) and $\mathrm{E}$ (decreased from 4 to 2) decreased significantly. Notably, the participants demonstrated improvement in their spelling grades after they participating in the intervention repetitively for five consecutive weeks.

According to Rana, Ardichvili, and Polesello (2016), activities that promote the connection of learners' previous knowledge with new information result in active learning, which leads to more effective learning. Evidently, Google Classroom provides a platform for active learning among peers (Mohd Shaharanee, Mohd Jamil, \& Mohamad Rodzi, 2018).

The spelling grades of the control group's pre- and post-tests (fifteen participants) are illustrated in Figure 4. The number of participants who got grade A remained the same (3), grade B also remained stable (2), grade C increased from 4 to 5 , grade $\mathrm{D}$ increased from 3 to 4 and grade $\mathrm{E}$ reduced from 3 to 1 between the pre-test and the post-test. 


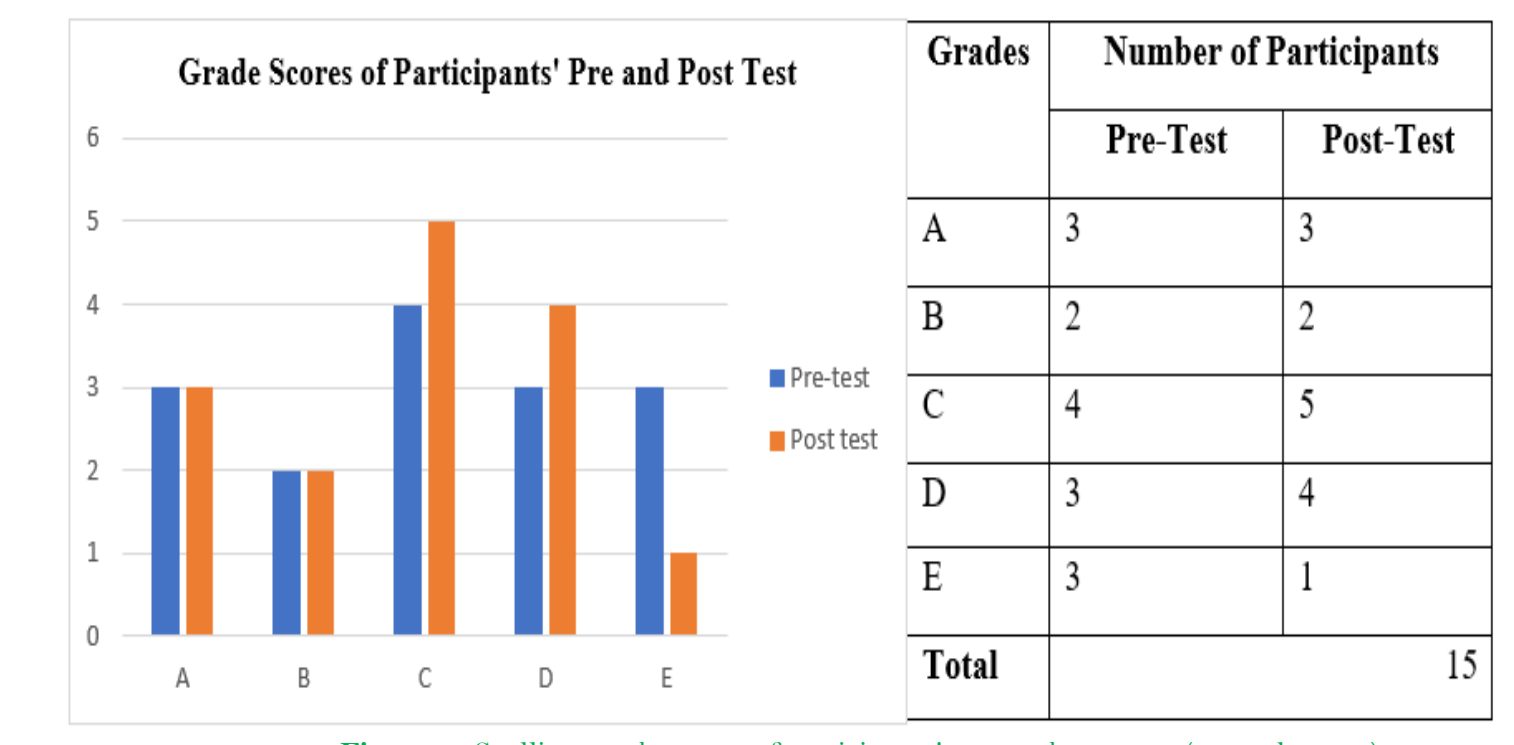

Source: Pre- and post-test of the intervention.

The score differential from the pre- to post-test in the experimental group (Figure 3) was more inclined towards grade A and B, while the control group (Figure 4), on the other hand, was more inclined towards C and D. This indicates that those who participated in the intervention on learning to spell (the experimental group) experienced a more significant improvement of spelling achievement compared to those who did not participate in the intervention (the control group). The rationale for employing an experimental and a control group was to ensure that the results attained from the pre- and post-test for both groups in determining the effectiveness of the intervention would be valid and reliable (Fraenkel et al., 2015).

Overall, the use of online learning motivated the learners to master the spelling of words. It revealed that the participants who took part in picture-based and audio methods showed a breakthrough in their spelling mastery, as also supported by Bakar et al. (2018). Pictorial cues along with auditory support can consolidate the spelling of words with the participants' existing knowledge to build lasting mental images and auditory memories for quick retrieval of correct spellings (Yunus, Lau, Mohd Khair, \& Yusof, 2020). The findings of this study were in line with the findings of Lau and Maslawati (2020), who found that the usage of ICT for online learning for elementary school ESL students enabled them to enjoy the benefits of improving their spelling skills.

\subsection{Participants' Perceptions}

Using screenshots taken of the pictorial and textual data, the participants' performance and feedback during the initial and final weeks were observed and compared with the field notes taken by the researcher during the intervention.

\subsection{Active Learning}

The students participated actively and were able to recall the spelling of the words due to the supportive learning environment and feedback that encouraged them in their attempts to spell the words correctly. The researcher could observe their gradual improvement from Module One to Module Five. In this study, the process of active learning ensured that students were engaged in meaningful thoughts and learning processes (Cattaneo, 2017). Clearly, this intervention is in line with the constructivist viewpoint that collaborative learning is essential in order to improve students' learning performance. Where, in this study, the learning performance refers to the mastery of spelling among the Year Four elementary school ESL students.

\section{a) Corrections and Compliments from Peers}

The participants took advantage of Google Classroom as an online learning platform to share their knowledge of spelling with their peers by helping each other to spell the words as well as providing their peers with feedback. They found that their learning process was made more purposeful through correcting and complimenting their peers' spelling and receiving peer feedback in turn. This is in line with the Theory of Constructivism relating to the More Knowledgeable Other (MKO), in which Thirusanku and Yunus (2014) elaborated that the MKO may be a peer of similar age who is more able to guide other learners. Findings from Majid (2012) explained this as a useful scaffolding strategy. It enabled the students to improve their spelling of words.

This finding is illustrated in Figure 5. Figure 5 displays corrective feedback from one of the participants when she noticed that her peer had misspelt a word during Lesson 1 ("I think picture 10 is riding a bike."). In addition, participants also gave compliments when their peers spelt words correctly. These compliments included:

\section{“Good job!” \\ "Great!"}

"Well done!"

The effectiveness of the feedback system was supported by Participants 2, 7 and 11 in the interview. Their responses were:

"I could share my spelling knowledge through commenting on my friends' spelling." (Participant 2 , Intermediate proficiency level)

"Err... I think it was helpful because my friends and I could correct each other's mistakes and give praises when our spelling of words was correct." (Participant 7, Advanced proficiency level)

"...can help each other." (Participant 11, Low proficiency level) 
Pictorial and Textual Data

Hi everyone. Thls week we will be learning the spelling of 10 words. These words are taken from the words you have learnt
earlier in Module 1 of your Year 4 textbook. Try to spell the words based on the pietures and audio pronunciation of the
words as provided, You may also correct your friends' spelling of words. Once done, you can answer the spelling quiz, Good
luck and have fun!

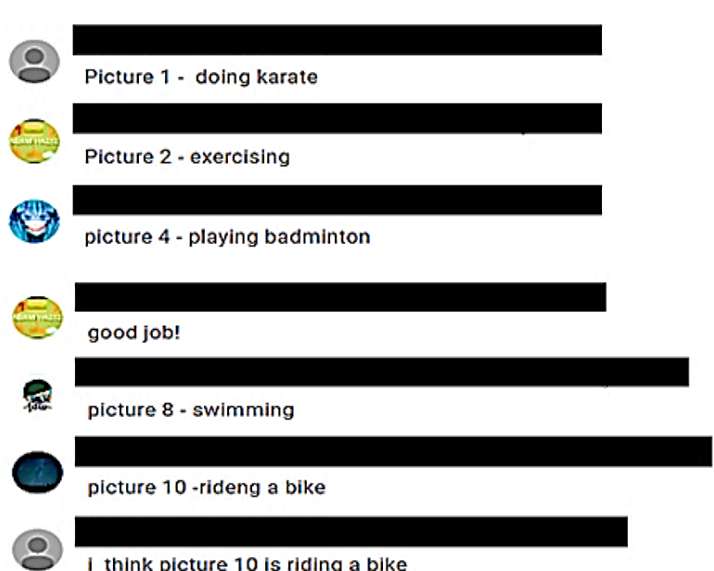

Lesson 1

The participants of the mixed-proficiency level were seen to be actively participating, as illustrated in the first lesson of the intervention, focusing on the spelling of words in Module One. They were willing to try to spell the words. They also praised and corrected each other's work where necessary.

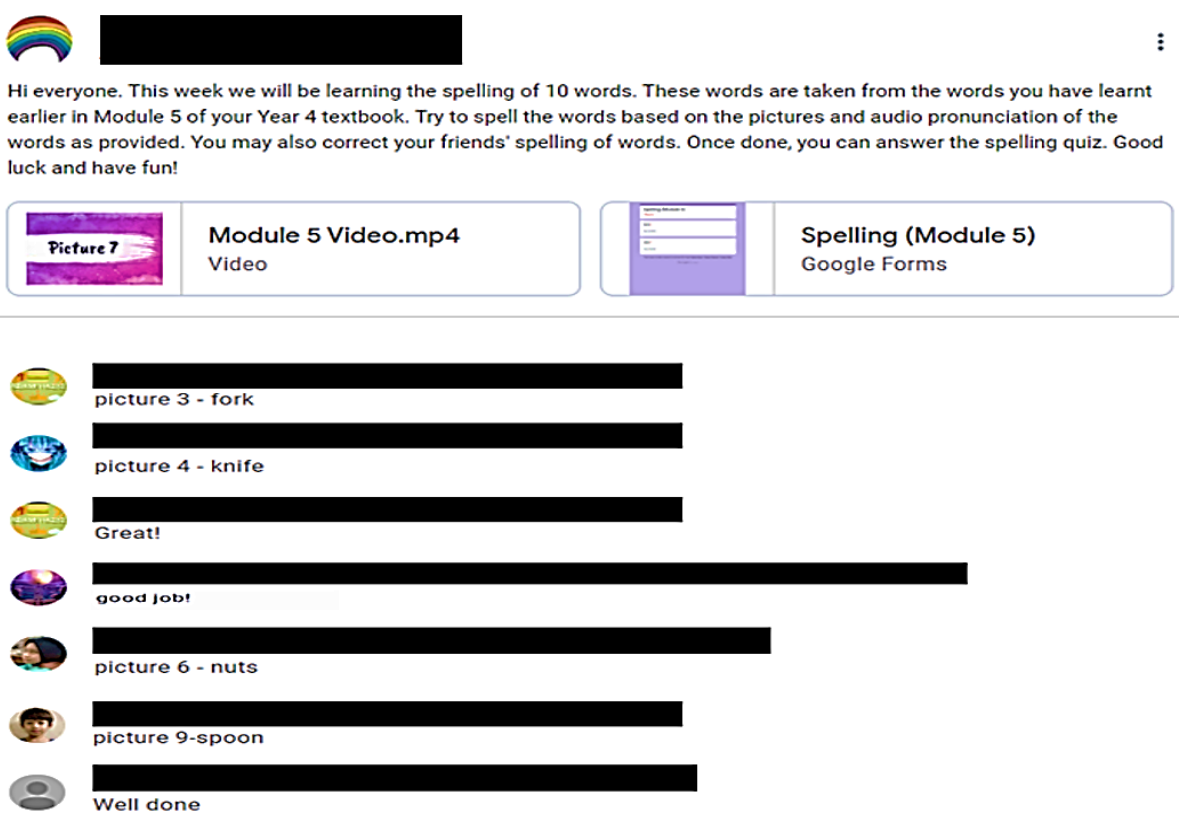

Lesson 5

The participants of the mixed-proficiency level were seen to be actively participating, as illustrated in the final lesson of the intervention, focusing on the spelling of words in Module Five. They were willing to try to spell the words. They were giving more compliments to their peers which illustrated their improvement in mastering spelling.

Source: Spelling modules in google classroom.

\section{Notes}

-Active participation

-Willing to try

-Complimenting each other's work

\section{-Correcting \\ other's work \\ each \\ -Participants helped each other in the spelling of words}

-Active participation

\section{-Willing to try}

- More compliments on each other's work

\section{-Improvement} learning to spell

Participant 1 (Intermediate proficiency level) concurred that the online classroom allowed him and his peers to correct and compliment each other's spelling of words. He added that in conventional classroom lessons only the English teacher would correct their spelling mistakes ("Hmm...I could correct my friends' mistakes. They could also correct mine. But if we were in the class, only the teacher would correct our spelling mistakes.").

Furthermore, Participant 9 (Intermediate proficiency level) added that she was glad to receive compliments from her peers, particularly when she spelt the words correctly. ("I felt happy when my friends praised me for spelling the words correctly".)

This is in accordance with Krashen's Affective Filter Hypothesis in which Schutz (2019) explained that when learners have self-confidence and a good self-image of themselves, their level of anxiety could be lowered, leading to a lowering of the affective filter. Consequently, learners could perform better in second language learning. In this study, this may have contributed to the participants' improvement in spelling the words. 


\section{b) Weekly Practices}

The participants were drilled repetitively by the teacher for five consecutive weeks throughout the intervention to ensure their mastery in the spelling of words. The participants felt that they improved in their spelling of words after the intervention. This is illustrated through the following interview responses from the participants:

"Lots of practices during MCO. I can spell better now." (Participant 4, Low proficiency level)

"Yes, after all the practices in Google Classroom, I have learned some ways to improve my spelling". (Participant 6, Advanced proficiency level)

Participant 2 (Intermediate proficiency level) agreed by stating that he had improved in his spelling through weekly spelling practices with his peers, who have helped to correct his spelling ("Every week, my friends will help to correct my spelling. I learned a lot from them.").

The Theory of Behaviorism was applied, of which Lim et al. (2012) argued that it promoted the gain of knowledge through comprehensive training through multiple repetitions, drilling practice and learning engagement. They added that the rationale of this theory in learning is that it creates a progression of the building blocks for meaningful learning.

\subsection{Motivation}

Based on Figure 5 and also the interview responses, the participants - who are generation $\mathrm{Z}$ millennials or socalled digital natives - demonstrated enthusiasm and confidence towards mastering spelling via Google Classroom during the MCO due to the COVID-19 pandemic. Heggart and Yoo (2018) conceded that there is a host of interactive tools available in Google Classroom which could stimulate active participation and teamwork among the users.

\section{a) Attractive Features}

Participant 1 (Intermediate proficiency level) felt that this spelling lesson offered an exciting and timely intervention since it was conducted virtually, particularly during the COVID-19 pandemic ("Nice spelling lessons during COVID-19 pandemic."). All the participants perceived the features of Google Classroom as attractive. They enjoyed the colorful pictures with the audio pronunciation, which acted as a guide for them to spell (type) the words. They opined that this activity was different from the conventional spelling lessons they had in class.

"It was fun because I could learn to spell with pictures and the word pronunciation. I like." (Participant 4, Low proficiency level)

"I like it because it was so enjoyable...I could see pictures and listen to how the words were being pronounced. Different from the spelling lessons in class." (Participant 2, Intermediate proficiency level)

Participant 10 (Low proficiency level) claimed that she liked the intervention because it was comparable to a game that required her to spell the words. ("I like... it's like playing a game and answer the spelling questions and quiz.")

Besides spelling the words, they were thrilled that they were able to comment on their peers' spelling. They either complimented or corrected their peers' spelling.

"I like to correct my friend's spelling mistakes and they also like to correct my spelling mistakes in

Google Classroom. So, we learn together." (Participant 9, Intermediate proficiency level)

"I like to comment on my friends' work and they could comment on mine. Also, the quiz was enjoyable." (Participant 15, Advanced proficiency level)

The intervention enabled them to have active communication among themselves. They enjoyed helping each other in learning to spell the words.

\section{Conclusion and Recommendations}

21 st century education demands serious attention to ensure all students are well-equipped with 21 st century skills (Suhaimi, Maslawati, \& Yamat, 2019). Teachers must utilize Information and Communication Technology in their lessons and reconceptualize the methods used to teach students spelling. The integration of Google Classroom in teaching and learning, as in this intervention, adheres to the student-centered teaching and learning approach proposed in the Malaysia Education Blueprint. The participants in this study demonstrated significant improvement, as well as positive perceptions of the use of Google Classroom, in mastering spelling during the COVID-19 pandemic.

The interventions used in this study could be expanded to other ESL elementary school students in order to spark their motivation and ensure purposeful learning in mastering spelling at their own individual pace. Further research could be conducted to study the effectiveness of Google Classroom in teaching spelling to ESL students in secondary schools, since this study was limited to elementary school ESL students. Other potential studies may involve the integration of Google Classroom in the teaching and learning of other language skills during a lockdown in times of a pandemic, namely, listening, speaking, reading and writing.

\section{References}

Ahmadi, M. R. (2018). The use of technology in English language learning: A literature review. International Journal of Research in English Education, 3(2), 115-125. Available at: org/10.29252/IJREE.3.2.115/.

Amin, F. (2012). British or American English lifestyle. The star. Retrieved from: https:// www.thestar.com.my/lifestyle/viewpoints/mindour-english/2012/03/06/british-or-american-english.

Ary, D., Jacobs, L. C., \& Sorensen, C. K. (2010). Introduction to research in education (8th ed.). Belmont: Wadsworth.

Bakar, S. F. A., Fauzi, F. H., Yasin, N. F. M., \& Yunus, M. M. (2018). Compound chunk: Telegram Autobot Quiz to improve spelling on compound nouns. International Journal of Academic Research in Progressive Education and Development, 8(1), 48-63. Available at: 10.6007/IJARPED/v8-i 1/5498.

Botley, S., Faizal, H., \& Dillah, D. (2007). Investigating spelling errors in a Malaysian learner corpus. Malaysian Journal of ELT Research, 3(1), 74-93.

Cattaneo, K. H. (2017). Telling active learning pedagogies apart: from theory to practice. Journal of New Approaches in Educational Research, 6(2), 144-152. Available at: 10.7821/naer.2017.7.237. 
Chung, A. K. Y., \& Yunus, M. M. (2021). Using peer-modo feedback at the pre-writing stage to improve year 4 pupils' writing performance. Journal of Education and E-Learning Research, 8(1), 116-124. Available at: 10.20448/journal.509.2021.81.116.124

Cook, V. (1997). L2 Users and English spelling. Journal of Multilingual and Multicultural Development, 18(6), 474-488. Available at: $10.1080 / 01434639708666335$.

Creswell, J. W. (2014). Educational research: planning, conducting, evaluating quantitative and qualitative research (4th ed.). Lincoln: Pearson New International Edition.

Fraenkel, J. R., Wallen, N. E., \& Hyun, H. H. (2015). How to design \& evaluate research in education (9th ed.). New York: McGraw-Hill Education.

Hashim, H. (2018). Application of technology in the digital era education. International Journal of Research in Counseling and Education, 2(1), doi.org/, 2(1), 1-5. Available at: 10.24036/002za0002.

Heggart, K. R., \& Yoo, J. (2018). Getting the most from google classroom: A pedagogical framework for tertiary educators. Australian Journal of Teacher Education, 43(3), 140-153. Available at: 10.14221/ajte.2018v43n3.9.

Jamshed, S. (2014). Qualitative research method: Interviewing and observation. Journal of Basic and Clinical Pharmacy, 5(4), 87-88. Available at: 10.4103/0976-0105.141942.

Krashen, S. D. (1985). The input hypothesis: Issues and implications. New York: Longman.

Lau, E. Y. Y., \& Maslawati, M. (2020). Utilising e-learning to assist primary school ESL students in learning to spell during COVID-19 pandemic: A literature review. Creative Education, 11(8), 1223-1230. Available at: 10.4236/ce.2020.118091.

Lee, L. T. (2020). S.O.P proposals for schools. Opinion. New Straits Times. Retrieved from https://www.nst.com.my/opinion/letters/2020/05/592656/sop-proposals-schools.

Lim, C. S., Tang, K. N., \& Kor, L. K. (2012). Drill and practice in learning (and beyond). In Seel, N.M. (Eds) Encyclopedia of the Sciences of Learning: Springer.

Lynch, M. (2018). How to use Google classroom to create the perfect digital learning environment. The Tech Advocate. Retrieved from https://www.thetechedvocate.org/how-to-use-google-classroom-to-create-the-perfect-digital-learning-environment/.

Mahalingam, K., \& Md Yunus, M. (2017). Good language learners and their strategies: An insight. Proceedings of the ICECRS, 1(1), 359-366. Available at: https://doi.org/10.21070/picecrs.v 1i1.504.

Majid, A. H. (2012). Blended scaffolding strategies through Facebook to aid learning and improving the writing process and writing performance. IOSR Journal of Humanities and Social Science, 1(4), 36-40.

Ministry of Education Malaysia. (2018). Primary school standard curriculum. National School English. In Curriculum and Assessment Standard Document Year 4. Putrajaya: Curriculum Development Division.

Mohd Shaharanee, I. N., Mohd Jamil, J., \& Mohamad Rodzi, S. S. (2018). The application of Google Classroom as a tool for teaching and learning. Journal of Telecommunication, Electronic and Computer Engineering, 8(10), 5-8.

Perveen, U., \& Akram, F. (2014). A comparative study to know the causes of spelling errors committed by learners of English at elementary level in distract Kasur and Lahore in Pakistan. European Academic Research, 2(2), 2601-2622.

Rahman, D. (2020). A reckoning for online learning in times of crisis. Opinion, The Star. Retrieved from https://www.thestar.com.my/opinion/columnists/whats-your-status/2020/03/24/a-reckoning-for-online-learning-in-times-ofcrisis.

Rana, S., Ardichvili, A., \& Polesello, D. (2016). Promoting self-directed learning in a learning organisation: Tools and practices. European Journal of Training and Development, 4O(7), 470-489. Available at: 10.1108/EJTD-10-2015-0076.

Randhawa, S. K., \& Saroa, C., S. (2014). Study of spell-checking techniques and available spell checkers in regional languages: A survey. International Journal for Technological Research in Engineering, 2(3), 148-151.

Samuddin, K. M., \& Krish, P. (2018). English ortographic depth among Malay learners at a primary school. 3L: Language, Linguistics, Literature, 24(1), 56-68. Available at: 10.17576/3L-2018-2401-05.

Sarris, M., \& Panagiotakopoulos, C. (2011). Word spelling assessment using ICT: The effect of presentation modality. Themes in Science and Technology, 3(1), 93-118.

Schutz, R. E. (2019). Stephen Krashen's theory of second language acquisition. Retrieved from https:// www.sk.com.br/sk-krashenglish.html.

Simin, G., \& Sani, I. M. (2015). Effectiveness of ICT integration in Malaysian schools: A quantitative analysis. International Research Journal for Quality in Education, 2(8), 1-12.

Suhaimi, N. D., Maslawati, M., \& Yamat, H. (2019). The effects of Whatsapp in teaching narrative writing: A case study. Humanities $\Xi^{2}$ Social Sciences Reviews, 7(4), 590-602. Available at: 10.18510/hssr.2019.7479.

Supardi, S., \& Hasanah, E. (2020). Junior high school students' experiences of high technology-based learning in Indonesia. International Journal of Learning, Teaching and Educational Research, 19(5), 153-166. Available at: https://doi.org/10.26803/ijlter.19.5.9.

Thirusanku, J., \& Yunus, M. M. (2014). Status of English in Malaysia. Asian Social Science, 10(14), 254-260. Available at: 10.5539 /ass.v10n 14 p254.

Treiman, R., Kessler, B., \& Caravolas, M. (2019). What methods of scoring young children's spelling best predict later spelling performance. Journal of Research in Reading, 42(1), 80-96. Available at: 10.1111/1467-9817.12241.

Vygotsky, L. S. (1978). Mind in society: The development of higher psychological processes. Cambridge: Harvard University Press.

Westwood, P. (2014). Teaching spelling: Exploring common sense strategies and best practices. New York: Routledge.

World Bank. (2020). World bank education global practice guidance note on remote learning \& COVID-19. Retrieved from http://documents.worldbank.org/curated/en/531681585957264427/pdf/Guidance-Note-we-Remote-Learning-and-COVID19.pdf.

World Health Organization. (2020). Coronavirus. Health topics. World Health Organization. Retrieved from https:// www.who.int/healthtopics/coronavirus \#tab=tab_1/.

Yeoh, A. (2020). MCO: Telcos to offer free 1GB data daily from April 1, here's what you should know. The Star. Retrieved from https://www.thestar.com.my/tech/tech-news/2020/03/27/mco-telcos-to-offer-free-1 gb-data-daily-from-april-1-here039s-whatyou-should-know/.

Yunus, M. M., Lau, E. Y. Y., Mohd Khair, A. H., \& Yusof, N. M. (2020). Acquisition of vocabulary in primary schools via GoPic with QR code. International Journal of English Language and Literature Studies, 9(3), 121-131. Available at: https://doi.org/10.18488/journal.23.2020.93.121.131. 